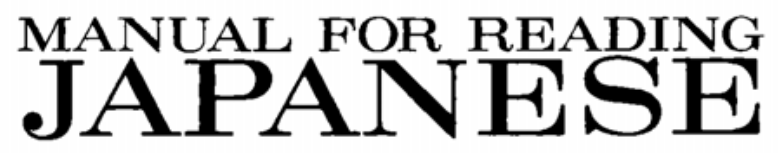


PALI Language Texts: Japanese

(Pacific and Asian Linguistics Institute) 


\title{
MANUAL FOR READING
}

\author{
DALE P. CROWLEY \\ with the assistance of \\ YOSHIYUKI AND YOKO KAWATA
}

The University Press of Hawaii

Honolulu, 1972 
Copyright $\odot 1972$ by The University Press of Hawaii All rights reserved

Library of Congress Catalog Card Number 72-75796 ISBN 0-8248-0231-4

Manufactured in the United States of America 


$$
\begin{aligned}
& \text { 若私湢 } \\
& \text { 心名曰音 } \\
& \text { )考本の }
\end{aligned}
$$

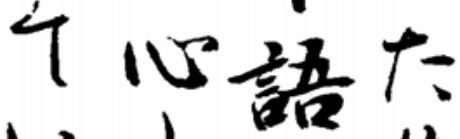

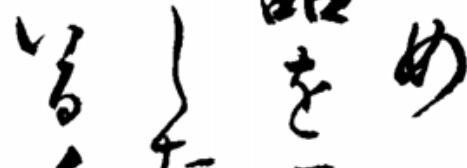

$$
\begin{aligned}
& \text { 人斿受 } \\
& 1=\left\{\begin{array}{l}
3: \\
0
\end{array}\right. \\
& \text { 献にに } \\
& \text { < }
\end{aligned}
$$


